\title{
IMPACT OF LAND USE ON FLORA COMPOSITION - TWO EXAMPLES FROM THE WARTA MOUTH NATIONAL PARK, POLAND
}

\author{
Magdalena WojciechowsKa \\ M. Wojciechowska, Institute of Botany and Landscape Ecology, Ernst Moritz Arndt University Greifswald, \\ Grimmer Str. 88, 17487 Greifswald, Germany, e-mail: chwalena@o2.pl
}

(Received: January 9, 2014. Accepted: July 14, 2014)

\begin{abstract}
AвSTRACT. Strong and long-lasting human activity in most European lowland river valleys results in narrowing the area of inudated ecosystems from wide floodplains to the space between embankments. This concerns especially regulation and drainage works, as well as hydrotechnical infrastructure construciton. The Warta Mouth National Park is a suitable region for inudated habitats research - over 5000 hectars of flood reservoir gathers here excess of water every year. It is one of the biggest flooded area in this part of Europe. The aim of this study was the analysis of flora changes over the dozen of years. The two inudated surfaces, different in respect of land use, were compared. Results indicate significant influence of land use on flora composition.
\end{abstract}

KeY wORDs: vascular flora, river valley, floodplain, land use, hydrological conditions

\section{INTRODUCTION}

Majority of lowland river valleys in Europe is strongly transformed by long term human activity (FALIŃSKi 2000). Natural flood zones have been reduced by regulation works. Polders suitable for agriculture have been created. Mowing and grazing is common on meager parts still influenced by flood (Nilsson et al. 1989, Amoros et al. 2000, KucharczyK 2003).

Natural disturbances in river valleys, which are regular floods, cause habitats' differentiation and aise of richness hotspots. The highest diversity of ecosystems appears in places of medium flood duration (FALIŃSKI 2000, Hood \& NAIMAN 2000, InNIs et al. 2000).

The aim of the article is an analysis of flora dynamics over a dozen years on two inundated surfaces different in respect of land use.

\section{STUDY AREA}

The Warta Mouth National Park is a proper area for analysis of flora dynamics in annual flood zone under different land use conditions. During the Warta river regulations ordered by Friedrich II von Hohenzollern over 5000 hectares of flood reservoir were left here. The area gathers the excess of water every year. Differences in annual levels of water table range up to 4 meters (ENGEL et al. 1998, WyPYCHOWSKA \& SZYMOŃSKI 2002).

Both history of melioration (embankments and pump stations building in $18^{\text {th }}$ and $19^{\text {th }}$ century) and economical factors (limitation of land use in 80 s of the $20^{\text {th }}$ century), show strong anthropopression on the natural environment (PiaseCKA 1974, MARCZEWSKI 1991). Presently natural succession distinctly appears on this hardly accessible area. Also the spread of alien species is visible in certain parts of the Park.

\section{MATERIALS AND METHODS}

The flora of the Warta Mouth NP was mapped in basic squares, which is continuation of the methods used by Chmiel et al. (2000). The side of every square is 500 meters. Mapping was conducted in 1994 and 2006.

In every square the number of habitats was specified. For every habitat one floristic releve was made. It consists of ordinal data such as number, designation of square, date and basic information about type of habitat and way of land use and of a list of plant species with cover values scale according to JАскOWIAK (1990). 


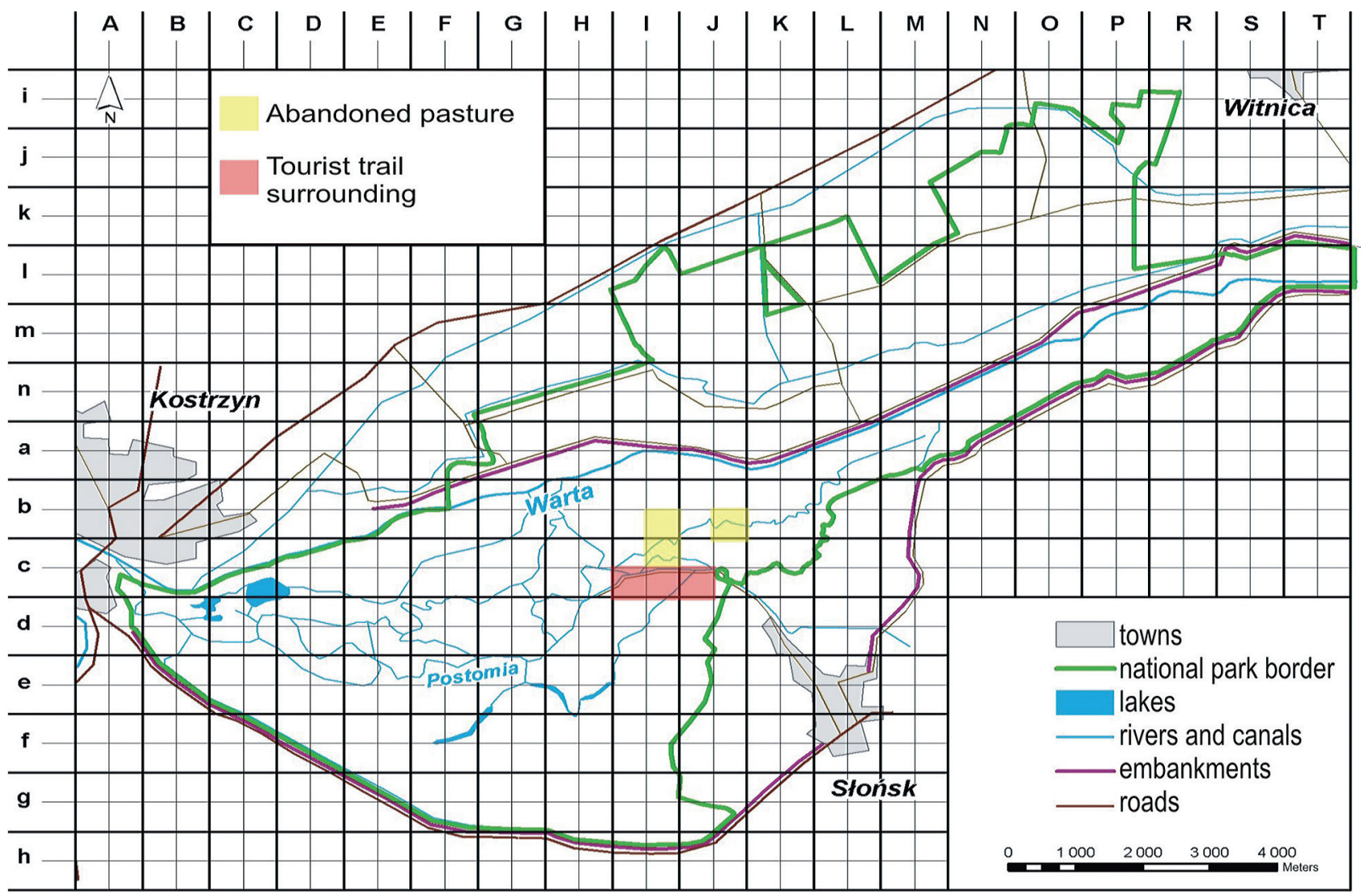

Fig. 1. Localization of research area

For the analysis two surfaces were chosen. First is a pasture abandoned in $80 \mathrm{~s}$ of $20^{\text {th }}$ century, second - neighbourhood of the main Park's touristic route, still used for grazing. Both of them cover an area of 0.75 ha (3 basic squares). Localization of the surfaces is shown on Figure 1. Directions of flora changes were analysed by detrended correspondence analysis (DCA).

\section{RESULTS}

\section{ABANDONED PASTURE}

A group of floristic releves made in 2006 stands out in this surface (canals, roadsides and Phalaris arundinacea rushes, Fig. 2). It is connected with willow shrubs. The comparison of floristic composition of releves shows a relationship of the first ordination axis with light conditions. There are more photophilous species in habitats on the left side of the diagram. The first axis significantly differentiates the occurrence of species. In every 2006 year releve Salix alba and S. triandra was observed. Salix viminalis was recorded in most of the floristic lists. Willow species was noted in all habitats, including rushes - here as a young specimen. One releve from 1994 corresponds to this group. It is a flooded sward used as a pasture (with Agrostis stolonifera and Eleocharis palustris) overgrown with Phalaris arundinacea and Glyceria maxima.
The second group of releves are habitats of open grazed areas (Fig. 2). Among floristic lists made in 1994 the presence of Plantago major, Potentilla anserina, Potentilla reptans and Pulicaria vulgaris points out.

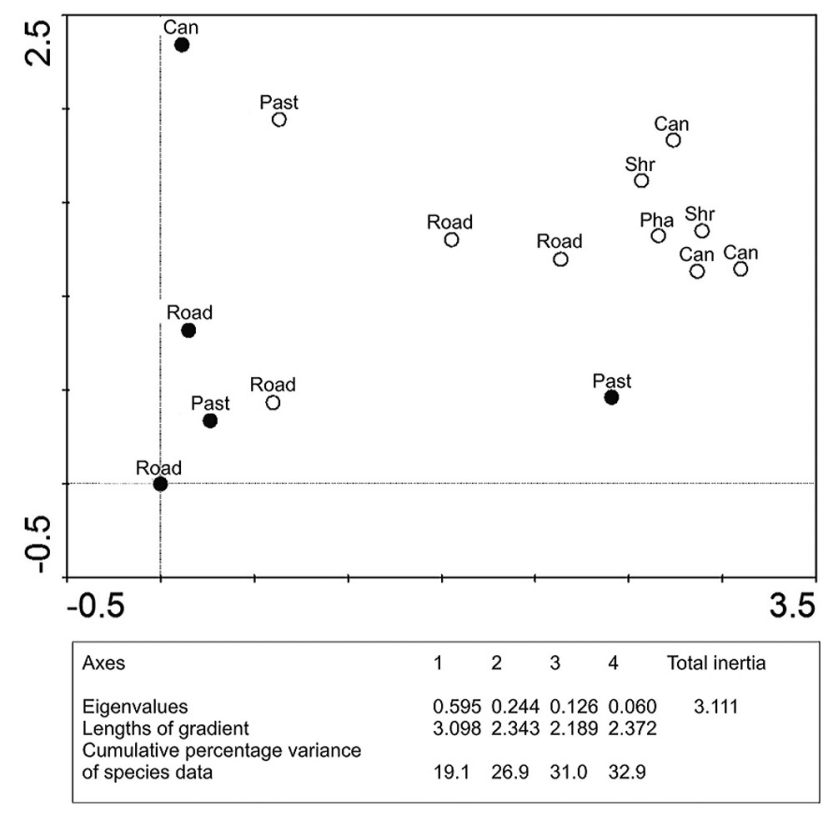

Fig. 2. DCA ordination based on floristic composition (abandoned pasture, 15 releves, the sum of species -73 )

Abbreviations: can - canal, past - pasture, pha - Phalaris arundinacea rush, road - roadside, shr - willow shrubs, $\bullet$ - releve made in 1994, o - releve made in 2006. 
The floristic composition of linear structures, such as canals or roadsides is unstable and strongly dependent on the surrounding environment. This is the reason of their resemblance to the nearby pasture. Two releves from 2006 (pasture and roadside) document the condition of open habitats.

\section{NEIGHBOURHOOD OF THE MAIN TOURISTIC ROUTE}

There is no separated group of releves made in surrounding of the main tourist trail (Fig. 3). Both habitats documented in1994 and 2006 are ordinate along moisture gradient. There are wet habitats on the left side of the diagram, like old riverbeds, river bank and canals. Places of shorter influence of flood gather on the right side. The moisture gradient is connected with anthropopression in this case. Habitats under human impact are situated in the right and central side of the diagram, like roads, pastures, rushes and flooded swards. There were no directional changes in the duration of flood over the period considered, so differences between floristic lists made in 1994 and 2006 are probably results of local flood condition in the year. The species composition of this place is stable.

Frequent occurrence of anthropophytes in the neighbourhood of the main touristic route, such as Convolvulus arvensis, Taraxacum officinale, Capsella bursa-pastoris, Conyza arvensis indicates regular human

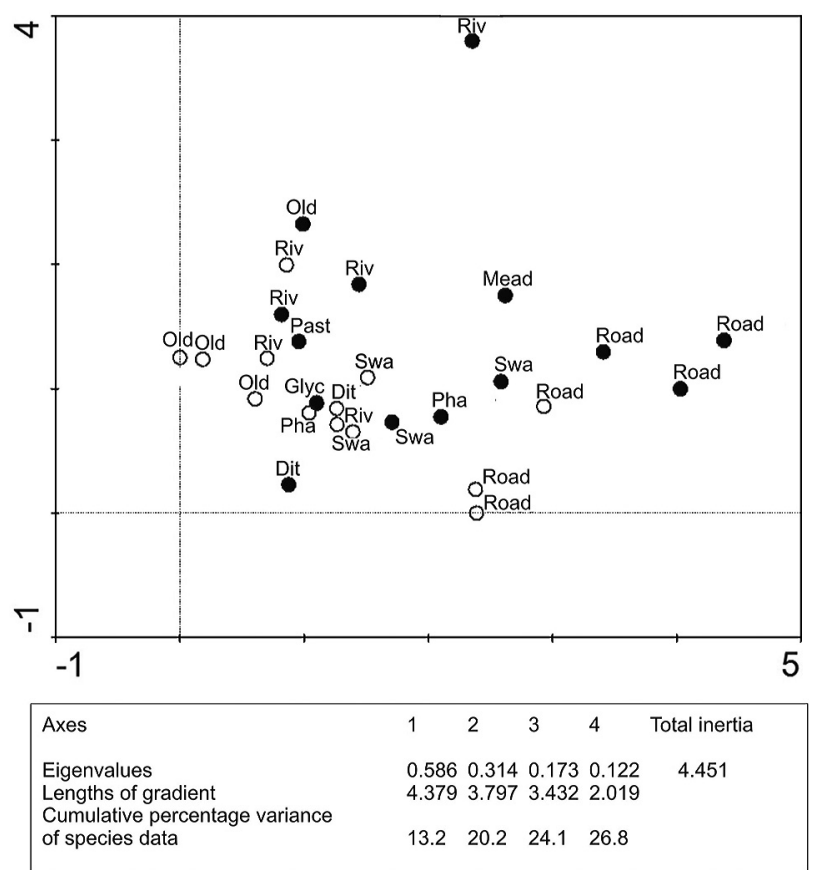

Fig. 3. DCA ordination based on floristic composition (neighbourhood of the main touristic route, 27 releves, the sum of species $-98)$

Abbreviations: dit - ditch, glyc - Glyceria maxima rush, mead meadow, old - old river bed, past - pasture, pha - Phalaris arundinacea rush, riv - river bank, road - roadside, swa - flooded sward, - - releve made in 1994, o - releve made in 2006. influence in this area. Stands of these species are restricted to the most anthropogenic habitats (mainly the roadsides).

\section{DISCUSSION}

Theory of succession is one of the oldest in plants' ecology. In models of succession it is assumed that changes of vegetation arise due to the passage of time and variability of the environment (FALIŃSKA 2004).

The structure and dynamics of vegetation in the river valley is strongly affected by intensity and duration of flood. The highest biodiversity of plant communities develops in areas or in time of medium flood impact. Too weak disturbances connected with water movement are insufficient to stop succession, too strong - can inhibit growth of vegetation (АмоROS et al. 2000, RENÖFÄLT et al. 2005). The succession rate is also influenced by land use. Mowing and grazing predominates on the flooded areas. The abandonment of open land leads to initiation of overgrowing by shrubs and trees.

The hypothesis of the secondary succession has been confirmed in the case of abandoned pasture. Samples collected in the beginning and in the end of the period under consideration are differentiated. The light gradient is the main differentiating factor. The process of periodic succession, characteristic to places with regular disturbances (FALIŃSKA 2004), is probable on this surface. The observed stage of vegetation could be interpreted as a stage of willow riparian forest Salicetum albo-fragilis establishment or formation of permanent willow shrub habitat Salicetum triandro-viminalis in conditions of inhibited growth of trees (by long lasting flood and ice cover).

The surroundings of the tourist route are dominated by grazed flooded swards with Agrostis stolonifera. Since 1994 there has been no floristic composition change in this surface. It is determinated by regular land use, which stops succession and results in stable list of species (МiкоŁАјсZAK et al. 2007). Regular grazing by cattle inhibits growth of shrubs and tall herbs including invasive Xanthium riparium. Low vegetation is proper for geese, which graze here both during their breeding season (graylag goose Anser anser) and migration period (bean goose Anser fabalis, greater white-fronted goose Anser albifrons). Differences between releves, made in 1994 and 2006, occur probably due to flood duration in a given year.

Many authors have suggested that river valleys ecosystems under regular influence of disturbances (i.e. flood) last relatively long, because disorders stop the succession. Contrary not disturbed habitats last shorter (Аmoros et al. 2000, BornetTe et al. 2001). This thesis is only partly confirmed in the present study. Both compared surfaces are situated on floodplain inundated every year, but only on one of them the succession is limited. This is the area 
regularly grazed (i.e. tourist trail surrounding). The abandoned pasture overgrows with willow species despite the annual flood over just the dozen of years. This surface should be studied to confirm or deny the development of riparian forest.

The main factor that influences the flora composition in all the Warta Mouth National Park are water conditions (ENGEL et al. 1998). However, this analysis points out the importance of land use in this area. It seems that land use is the crucial factor determining dynamics of flora in this case. The succession documented in this work did not affect the floristic composition of the whole national park. The new species are not foreign species, therefore the presented floristic changes are quantitative, and not qualitative.

\section{ACKNOWLEDGMENTS}

I wish to thank professor Bogdan Jackowiak and professor Julian Chmiel from Department of Plant Taxonomy, Adam Mickiewicz University of Poznań, for providing the original data from 1994 and for any substantive support.

\section{REFERENCES}

Amoros C., Bornette G., Henry C.P. (2000): A vegetation-based method for ecological diagnosis of riverine wetlands. Environmental Management 25(2): 211-227.

Bornette G., Piegay H., Citterio A., Amoros C., Godreau V. (2001): Aquatic plant diversity in four river floodplains: a comparision at two hierarchical levels. Biodiversity Conservation 10: 1683-1701.

Chmiel J., Jackowiak B., Latowski K., Żukowski W. (2000): The vascular plants of the Słońsk Nature Reserve (western Poland). Biological Bulletin of Poznań 37 (2): 205-233.

Engel J., JACKOWIAK B., KuCZyŃSKi L., OsIeJUK T.S. (1998): Plan ochrony Rezerwatu Przyrody Słońsk. Część ogólna. Typescript. Poznań-Słońsk.
FALIŃSKA K. (2004): Ekologia roślin. Wyd. Nauk. PWN, Warszawa.

FALIŃsKi J.B. (2000): Rzeczne wędrówki roślin. In: J. Kułtuniak (ed.). Rzeki, kultura - cywilizacja - historia. Wydawnictwo Śląsk, Katowice.

Hood W.G., Naiman R.J. (2000): Vulnerability of riparian zones to invasion by exotic vascular plants. Plant Ecology 148: 105-114.

InNis S.A., Naiman R.J., Elliott S.R. (2000): Indicators and assessment methods for measuring the ecological integrity of semi-aquatic terrestial environments. Hydrobiologia 422/423: 111-131.

JACKOWIAK B. (1990): Antropogeniczne przemiany flory roślin naczyniowych Poznania. Wyd. Nauk. UAM, Seria Biologia 42.

KuCHARCZyK M. (2003): Phytogeographical roles of lowland rivers on the example of the Middle Vistula. Maria Curie-Skłodowska University Press, Lublin.

Marczewski J. (1991): Kostrzyn nad Odrą. Dzieje dawne i nowe. Instytut Zachodni, Poznań.

MikoŁajczak Z., Dobicki A., Nowakowski P., WoJCIECHOWSKa M., GŁOWACKI J. (2007): Skład florystyczny i wartość pokarmowa biomasy jako paszy dla bydła $z$ wybranych zbiorowisk trawiastych Parku Narodowego „Ujście Warty”. Prace i Materiały Zootechniczne 64: 23-40.

Nilsson C., Grelsson G., Johansson M., Sperens U. (1989): Patterns of plant species richness along riverbanks. Ecology 70: 77-84.

PiAseCKA J.E. (1974): Zmiany hydrologiczne doliny Warty w okresie ostatnich 200 lat. Czasopismo Geograficzne 45, 2: 229-238.

ReNÖFÄLt B.M., JANSSON R., Nilsson C. (2005): Spatial patterns of plant invasiveness in a riparian corridor. Landscape Ecology 20: 165-176.

WypYchowsKa D., SZYMOŃSKI P. (2002): Park Narodowy: „Ujście Warty”. MULTICO Oficyna Wydawnicza, Warszawa. 